\title{
Integration Rice Price And Farmers Welfare With Error Correction Model Analysis
}

\author{
Yogi Makbul \\ Institut Teknologi Bandung \\ Sudrajati Ratnaningtyas \\ Institut Teknologi Bandung \\ Senny Soniaty \\ Institut Teknologi Bandung
}

\begin{abstract}
This research analyzes the short- and long-term influence of rice prices on the welfare of Indonesian farmers using an error correction model. Drawing upon data from Indonesia's Central Bureau of Statistics, it reveals that rice prices exert significant positive short-run effects and no significant long-run influence on farmers' welfare. These findings extend or refine results from earlier studies that lack the time series perspective of our research. They also support policy intervention by the Indonesian government to increase farmers' welfare and assure food supply.
\end{abstract}

Keywords: Rice prices; farmer welfare; error correction model; Indonesia

\section{INTRODUCTION}

Improving farmers' welfare is one of the objectives of the Indonesian agriculture program (Kementerian Pertanian, 2015). Based on Law no. 19 of 2013, farmers are defined as Indonesian citizens who conduct farming in the fields of food crops, horticulture, plantations, and livestock.

Farmer welfare is the focus of the Indonesian government because $49 \%$ of poor households in Indonesia rely on the agricultural sector (BPS, 2018). Farmers are the main actors in agriculture who should get the rights commensurate with the spending of time, energy, and thought that had been devoted to working in agriculture (Kementerian Pertanian, 2015). The level of welfare of farmers is measured by (1) per capita income, (2) poverty level, and (3) level of agricultural household food insecurity (Kementerian Pertanian, 2015). Income is deriving from how much money is generating from the sale of farm products. The price of agricultural commodities correlates with farmers' income which impacts on the welfare of farmers.

Rice is one of Indonesia's strategic staples besides corn and soybeans. Rice is still a staple food for Indonesian people and a priority in developing agriculture towards food security. Food security is a condition for the fulfillment of food for the country up to individuals, as reflected in the availability of sufficient food, both in quantity and quality, safe, diverse, nutritious, equitable, and affordable and not contrary to the religion, beliefs and culture of the community, to be able to live healthy, active and productive in a sustainable manner (Badan Ketahanan Pangan, 2012)

Rice is still used as a staple food by more than 95\% of Indonesia's population, making rice a benchmark of various economic indicators. Food purchasing power shows the level of community welfare (Hermawan, Fitrawaty, \& Maipita, 2017). This is also in line with 
Simatupang and Timer (2008) statements that the growth of rice production is considering as the most critical indicator of agricultural development in Indonesia. According to them, rice is the main crop for small agriculture, and the rice value chain is a significant sector of the rural economy. Rice is still a staple food, and domestic demand for rice is substantial.

Rice prices in Indonesia experienced fluctuations, especially after the 1998 monetary crisis. Inflation causing food prices, including price to rise sharply. This increasing price has caused unrest for consumers and producers, in this case farmers, so that in 2017, the Government of Indonesia issued Minister of Trade Regulation No 27/M-DAG/PER/5/2017 concerning Determination of Reference Prices for Purchases in Farmers and Reference Prices for Sales in Consumer and Minister of Trade Regulation Number 57/M-DAG/PER/8/2017 concerning Determination of the Highest Retail Price of Rice. (Kementerian Perdagangan, 2017)

Food prices influence welfare and poverty. Vu and Glewwe (2011), conducted a study of the effect the food price to farmer welfare in Vietnam. The research is using the farmers household. The results showed that household welfare is increasing an increase in the price of rice alone increased average household welfare by $5 \%$ in 2007-2008 and increased poverty by 0.3 percentage points during the same period.

Minot and Dewina (2013), examined the effect of changes in food prices on household welfare in Ghana. Using household survey data, they tested the distribution effect of higher prices for wheat, rice, and food in general. The results showed that the average price of wheat accounted for $6 \%$ of expenditure and 5\% of income in Ghana. The retail price of wheat which increased by 81\% during 2007-2008 shows that there was an increase in the poverty rate of 0.6 percentage points in the short term. Rice accounts for $3 \%$ of consumption. Simulations of rice prices which rose 36\% in 2007-2008 show that farmers benefited from rising prices, but almost every other group was affected by the increase in rice prices.

Allo, Satriawan, \& Arsyad (2018) conducted research on the impact of rising food prices on the welfare of farmers in Indonesia. Their results showed that the direct effects of rising food prices on the welfare of farmers in Java and Bali are more significant than for those who live outside of Java.

Nakelse, Dalton, Hendricks, \& Hodjo (2018) analyze the implications of world cereal price shocks on the welfare of rural households in Burkina Faso. The causal relationship between the world and domestic cereal prices is formed using the Error Correction Framework to measure and separate the short-term and long-term effects on local prices from changes in world prices. In their research, they combined price elasticity, transmission, purchase, and sales coefficients to estimate changes in household welfare levels caused by global price shocks. Overall, the price increases experienced during the 2008-2009 period were associated with improvements in the welfare of rural farmers because the effects of producers outstripped consumer effects. The rise in prices during the period from 2006 to 2014 translated into an increase in welfare.

Farmer's welfare is a vital object of this study, wherein previous studies no one focused on discussing the effect of food prices on farmers' welfare. Error Correction Model (ECM) analysis is used to determine the effect of short and long term. Many researchers use ECM to analyze the short-term and long-term effects of one variable to another, as did (Zare \& Azali, 2015); (Belinga, Zhou, Doumbe, Gahe, \& Koffi, 2016) and (Kingu, 2016). However, no one has used the analysis model to see the effect of food prices on the welfare of farmers. 
This research was conducted in a short time and had no time perspective. To enrich research on the effect of food prices on welfare, other studies with different perspectives are needed. This is the need for the novelty of science. So, we conducted research on the effect of food prices on the welfare of farmers in the view of a time series with short-term and long-term effects.

The purpose of this study is to analyze the effect of domestic food prices on farmers' welfare in the short and long term. The results of this study can help the Indonesian government in making policies and strategies to improve the welfare of farmers in terms of the effect of commodity prices on the market.

\section{Data}

\section{MATERIALS AND METHODS}

Independent variable $\mathrm{x}$ is monthly prices for medium-quality rice from Indonesia's Central Bureau of Statistics (Badan Pusat Statistik (BPS)) website (BPS, 2019) spanning January 2016 to December 2018. Dependent variable y is farmers' welfare. Its data are monthly Farmer's Terms of Trade for the Food Crops Subsector, the Indonesian government's measure of farmers' welfare from BPS (BPS, 2016); (BPS, 2017); (BPS, 2018). We adjusted prices and welfare using Indonesian inflation data from BPS (BPS, 2019)

\section{Analysis}

Since non-stationary data can prompt spurious regression (Gujarati \& Porter, 2009), the first step in ECM analysis is to assure data are stationary. We do so using the Augmented DickeyFuller (ADF) test per (Xu, Dong, Li, \& Li, 2011). The equation is

$$
y_{t}=\varphi y_{t-1}+\mu_{t}
$$

where Denotes the farmers' welfare at time t. $\varphi$ is the coefficient of farmers' welfare $(Y)$ at time $\mathrm{t}-1$. $\mu$ t is noise. Data are not stationary if $\varphi>1$.

$$
\Delta y_{t}=\alpha+\gamma \Delta x_{t}+\tau \hat{\mu}_{t-1}+\varepsilon_{t}
$$

In Eq. (2), the dependent variable Indicates the change in farmers' welfare at time t. $\alpha$ is constant. $\Upsilon$ is the coefficient for the change in prices or rice at time $t\left(x_{t}\right)$. If it is statistically significant, $x_{t}$ influences $y_{t}$ in the short run. We seek significance at $\alpha=0.05$. The long-term coefficient is . If it is statistically significant, $\mathrm{y}_{\mathrm{t}}$ has a long-term correlation with $\mathrm{x}_{\mathrm{t}}$. Subscript $\mathrm{t}$ is the parameter of variable $u$. It is the residual from

$$
y_{t}=\beta_{0}+\beta_{1} x_{t}+\mu_{t}
$$

The value of $u_{t}$ is determined by

$$
\hat{\mu}_{t}=y_{t}-\hat{\beta}_{0}-\hat{\beta}_{1} x_{t}
$$

\section{Descriptive Statistics}

\section{RESULTS}

Table 1 displays descriptive statistics.

Table 1. Descriptive Statistics

\begin{tabular}{lllll}
\hline Variables & Mean & Std. Deviation & Minimum & Maximum \\
\hline Rice Prices (IDR/Kg) & 7836.07 & 322.64 & 7402.65 & 8546.80 \\
Farmer's Terms of Trade (index) & 85.51 & 2.55 & 81.71 & 92.80 \\
\hline
\end{tabular}


Table 1 shows descriptive statistics for the independent variable (monthly average prices for rice in Indonesian Rupiah (IDR) per kilogram) and the dependent variable (farmers' terms of trade, an index of farmers' welfare). Figure 1 graphs times series from the descriptive statistics.

Figure 1. Graphics Rice Prices and Farmers Term of Trade

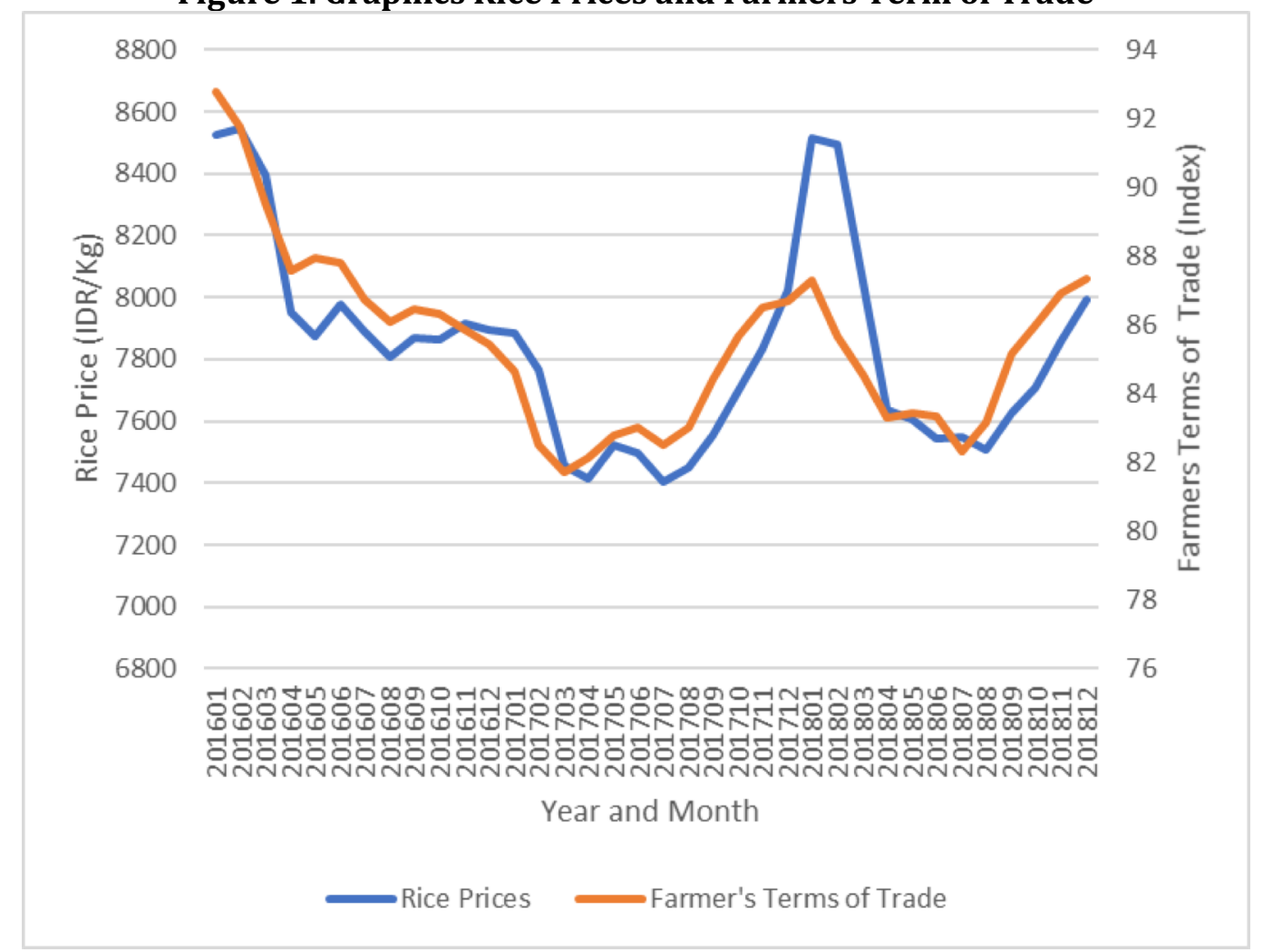

Figure 1 graphs rice prices on the left axis and farmer's terms of trade on the right, the Indonesian government's index of farmers' welfare (BPS, 2017, p. 1). Figure 1 indicates prices correlate positively with welfare over the period studied (orange and blue lines). ECM analysis must confirm that insight.

\section{ECM analysis}

The first step is to determine whether data are stationary using ADF. Results in Table 2 shows that data for farmers' welfare are stationary at $5 \%$ confidence.

Table 2. Augmented Dickey-Fuller Test for Farmers' Welfare

\begin{tabular}{lccc}
\hline & & t-Statistic & Prob.* \\
\hline \multirow{2}{*}{ Augmented Dickey-Fuller test statistic } & -3.123204 & 0.0342 \\
Test critical values: & 1\% level & -3.639407 & \\
& 5\% level & -2.951125 & \\
& $10 \%$ level & -2.614300 & \\
\hline
\end{tabular}

Table 3 shows that data for rice prices are stationary at 1\% confidence (t-statistic $-3.8902>$ critical value 3.6394). Data for both variables are stationary and acceptable for ECM analysis. 
Table 3. Augmented Dickey-Fuller test for rice prices

\begin{tabular}{lccc}
\hline & & t-Statistic & Prob. $^{*}$ \\
\hline & & & \\
Augmented Dickey-Fuller test statistic & -3.890221 & 0.0053 \\
Test critical values: & 1\% level & -3.639407 & \\
& 5\% level & -2.951125 & \\
& 10\% level & -2.614300 & \\
\hline
\end{tabular}

Table 4 reveals the ECM analysis of rice prices and farmers' welfare. It shows that $\mathrm{C}$ is constant. $\mathrm{D}(\mathrm{X})$ indicates short-run influence; its coefficient is positive and significant. $U_{(-1)}$ means longrun impact; its adjusted coefficient (a) is not statistically significant. Results show that rice prices influence farmers' welfare in the short run but not the long run.

Table 4. Rice Prices and Farmers' Welfare

\begin{tabular}{lllll}
\hline Variable & Coefficient & Std. Error & t-Statistic & Prob. \\
\hline & & & & \\
$\mathrm{C}$ & -0.109421 & 0.151853 & -0.720572 & 0.4764 \\
$\mathrm{D}(\mathrm{X})$ & 0.004016 & 0.000859 & 4.676510 & 0.0001 \\
$\mathrm{U}(-1)$ & -0.108101 & 0.108790 & -0.993666 & 0.3278 \\
\hline & & & & \\
$\mathrm{R}^{2}$ & 0.430511 & Mean dependent var & -0.174733 \\
Adjusted R & 0.394917 & S.D. dependent var & 1.150405 \\
S.E. of regression & 0.894866 & Akaike info criterion & 2.697532 \\
Sum squared resid & 25.62514 & Schwarz criterion & 2.830847 \\
Log likelihood & -44.20680 & Hannan-Quinn criterion & 2.743552 \\
F-statistic & 12.09534 & Durbin-Watson stat & 1.165134 \\
Prob. (F-statistic) & 0.000122 & & & \\
\hline
\end{tabular}

\section{DISCUSSION}

This research extends findings by $\mathrm{Vu}$ and Glewwe (2011) and Minot and Dewina (2013) and refines those of Nakelse et al. (2018) that food prices correlate positively farmer's welfare. As noted, the previous two studies lack the time series perspective of our research. Nakelse et al. (2018) conclude that food cereal prices correlate positively with household welfare, but we show that prices of rice during the period studied connect significantly with farmers' short-run but not long-term welfare.

The findings of food price research can affect the welfare of farmers because of the transmission of prices from food prices to the prices of farmers' products, then to the income of farmers and then to the welfare of farmers. The impact of rice prices on the prices of farmers 'products has found Makbul research (Makbul \& Ratnaningtyas, 2017), another step-by-step research transmission from food prices to farmers' welfare must be carried out to enrich the boundaries of this study.

The results of this study that the price of rice can affect the welfare of farmers have an impact on rice price policy. According to (Tsakok, 1990) rice price policy is government intervention on rice prices. An example of this intervention uses a trade mechanism. When the domestic price of rice is higher than the international price, the government is intervention with the import tariff according to the rules. For example, rule No. 93 of 2007 (Menteri Keuangan, 2007). This rule can maintain the price of rice in the domestic market. This policy is needed because rice is an outstanding staple food in Indonesia (Bulog, 2019). A high rice price policy is required to support that prices are higher than production costs (Dev \& Rao, 2010) The cost of rice production increases from time to time, to adjust for these costs the price of rice requires an increased price. Another reason is to increase farmers' income to maintain food security (Dev \& Rao, 2010) 
The short-term effect of high rice prices on farmers' welfare is possible because there is a gap between farmers and rice. Rice is a commodity derived from milled paddy. Farmers correlate directly with milled paddy but not with rice. However, when the price of rice fluctuates, farmers are also affected by this phenomenon. The price of rice does not touch the farmer level directly, but it can affect the price of the milled paddy, which directly affects the income of farmers. According to (Makbul \& Ratnaningtyas, 2017) that the integration of rice prices has a significant effect on the price of milled paddy in Indonesia.

In connection with this, the Government of Indonesia issued regulations on setting reference prices for purchases at farmers and reference prices for sales at consumers (Kementerian Perdagangan, 2017). In these regulations clearly made restrictions on the reference price of rice and other commodities. The reference price for purchases at farmers and the reference price for sales at consumers is an effort of the Government of Indonesia to monitor food prices.

\section{CONCLUSION AND IMPLICATIONS}

This study has traced the transmission from market prices through farmers' revenue to farmers' welfare and shows that prices of rice during 2016-2018 correlate significantly with Indonesian farmers' short-run but not long-term welfare.

Increasing farmers' welfare is one goal of Indonesia's national food program (Kementerian Pertanian, 2018), and our results justify government intervention to support the prices of rice. Tsakok (1990) endorses tariffs on imported rice when prices for domestic rice exceed prices internationally. Indonesia had that authority under rule No. 93 in 2007 (Menteri Keuangan, 2007). Rice is Indonesia's most famous food staple (Bulog, 2015), and policy is needed to maintain prices above production cost (Dev \& Rao, 2010). Farmers' production cost rises over time, justifying policies that keep pace. Policies that increase farmers' income also maintain food security (Dev \& Rao, 2010). However, the government must set prices carefully to avoid harming consumers and exacerbating poverty (Warr \& Yusuf, 2013). Future studies need to document more explicitly the transmission of food prices to farmers' welfare and specify prices on which support policies.

\section{ACKNOWLEDGMENT}

This research is funding by the Directorate General of Research and Development, Ministry of Research, Technology and High Education.

\section{References}

Allo, A. G., Satriawan, E., \& Arsyad, L. (2018). The Impact of Rising Food Prices on Farmers' Welfare In Indonesia. Journal of Indonesian Economy and Business, 33(3), 193-215.

Badan Ketahanan Pangan. (2012). UU No. 18 Tahun 2012. Retrieved 6 2019, 11, from Badan Ketahanan Pangan: http://bkp.pertanian.go.id/storage/app/media/uploaded-files/uunomor18tahun20121.pdf

Belinga, T., Zhou, J., Doumbe, D. E., Gahe, Z. S., \& Koffi, Y. S. (2016). Causality Relationship between Bank Credit and Economic Growth: Evidence from a Time Series Analysis on a Vector Error Correction Evidence from a Time Series Analysis on a Vector Error Correction. Procedia - Social and Behavioral Sciences, 235, 664-671.

BPS. (2016). Statistik Nilai Tukar Petani 2016 [Farmer's Terms of Trade Statistics]. Jakarta: Badan Pusat Statistik [Central Bureau of Statistics]. Retrieved 6 20, 2019, from https://www.bps.go.id/publication/2017/04/04/17c83ada5d0cb2a9e341c5a3/statistik-nilai-tukar-petani-2016.html

BPS. (2017). Statistik Nilai Tukar Petani [Farmer's Terms of Trade Statistics]. Jakarta: Badan Pusat Statistik [Central Bureau of Statistics]. Retrieved 6 20, 2019, from https://www.bps.go.id/publication/2018/04/06/34709474c981f5bf10e8f32b/statistik-nilai-tukar-petani2017.html 
BPS. (2018). Penghitungan dan Analisis Kemiskinan Makro Indonesia Tahun 2018 [The Calculation and Analysis of Indonesian Macro Poverty in 2018]. Badan Pusat Statistik, Sub Direktorat Statistik Kerawanan Sosial. Jakarta: Badan Pusat Statistik. Retrieved August 15, 2018, from https://www.bps.go.id/publication/download.html?nrbvfeve=NzhkNDQ5ZWRkYWFkODkyZTM4M2I3ZmQ5\&Xz mn=aHR0cHM6Ly93d3cuYnBzLmdvLmlkL3B1YmxpY2F0aW9uLzIwMTgvMTIvMjEvNzhkNDQ5ZWRkYWFkODky ZTM4M2I3ZmQ5L3BlbmdoaXR1bmdhbi1kYW4tYW5hbGlzaXMta2VtaXNraW5hbi1tYWtyby1kYW4taW5k

BPS. (2018). Statistik Nilai Tukar Petani [Farmer's Terms of Trade Statistics]. Jakarta: Badan Pusat Statistik [Central Bureau of Statistics]. Retrieved 6 20, 2019, from https://www.bps.go.id/publication/2019/04/05/5b772a0952bded5a7f611117/statistik-nilai-tukar-petani2018.html

BPS. (2019). Rata-Rata Harga Beras Bulanan di Tingkat Penggilingan Menurut Kualitas, 2013-2019 (Rupiah/Kg) [Average Monthly Rice Prices at Milling Rate by Quality, 2013-2019 (Rupiah / Kg)]. Retrieved 6 20, 2019, from Badan Pusat Statistik [Central Bureau of Statistics]: https://www.bps.go.id/dynamictable/2016/01/05/1102/rata-rata-harga-beras-bulanan-di-tingkatpenggilingan-menurut-kualitas-2013-2019-rupiah-kg-.html

BPS. (2019). Tingkat Inflasi Bulanan Gabungan 82 Kota [Combined Monthly Inflation Rate of 82 Cities]. Retrieved 6 21, 2019, from Biro Pusat Statistik [Central Bureau of Statistics]:

https://www.bps.go.id/statictable/2014/09/26/913/tingkat-inflasi-bulanan-gabungan-82-kota-sup-1-sup-2012100-.html

Bulog. (2015). Ketahanan Pangan [Food security]. Retrieved 9 8, 2015, from Badan Urusan Logistik [Logistics Agency]: http://www.bulog.co.id/ketahananpangan.php

Bulog. (2019). Ketahanan Pangan [Food Security]. Retrieved 4 3, 2019, from Bulog:

http://www.bulog.co.id/ketahananpangan.php

Dev, S. M., \& Rao, N. C. (2010). Agricultural Price Policy, Farm Profitability. Economic and political weekly, 45(26), 174-182. Retrieved 7 1, 2019, from https://www.epw.in/journal/2010/26-27/review-issues/agricultural-pricepolicy-farm-profitability-and-food-security.html

Gujarati, D. N., \& Porter, D. C. (2009). Basic Econometrics (5 ed.). New York: McGraw-Hill/Irwin.

Hermawan, W., Fitrawaty, \& Maipita, I. (2017). Factors Affecting the Domestic Price of Rice in Indonesia. JEJAK Journal of Eonomics and Policy, 10(1), 155-170.

Kementerian Perdagangan. (2017). Peraturan Menteri Perdagangan No. 27/M-DAG/PER/5/2017 tentang Penetapan Harga Acuan Pembelian di Petani dan Harga Acuan Penjualan di Konsumen [Regulation on Setting Reference Prices for Purchases at Farmers and Reference Prices for Sales at Consumers]. Retrieved August 15, 2019, from Kementerian Perdagangan [Ministry of Trade]: https://www.kemendag.go.id/files/regulasi/2017/05/05/27m-dagper52017-id-1496025997.pdf

Kementerian Pertanian. (2015). Rencana Strategis Kementerian Pertanian Tahun 2015-2019 [Strategies Plan of Ministry of Agriculture Year 2015-2019]. Retrieved 8 9, 2019, from Kementerian Pertanian [Ministry of Agriculture]: http://www1.pertanian.go.id/file/RENSTRA_2015-2019.pdf

Kementerian Pertanian. (2018). Undang-Undang no 18 Tahun 2018 Tentang Pangan [Law No. 18 of 2018 of Food]. (Kementerian Pertanian) Retrieved 6 5, 2019, from Kementerian Pertanian [Ministry of Agriculture]: http://perundangan.pertanian.go.id/admin/uu/UU-18-12.pdf

Kingu, J. (2016). Determinants of Foreign Direct Investment in Tanzania: Co-integration and Error Correction Model Analysis. Journal of Poverty, Investment and Development, 20, 26-34.

Makbul, Y., \& Ratnaningtyas, S. (2017). Analysis of the Integration of Rice and Paddy Prices in Indonesia Using a Vector Error Correction Model. International Journal of Applied Business and Economic Research, 15(10), 209-215.

Makbul, Y., \& Ratnaningtyas, S. (2017). How much does rice price influence milled paddy price? Analysis of price integration in Indonesia. Archives of Business Research, 5(3), 238-247.

Menteri Keuangan. (2007). Regulation of the Minister of Finance No. 93 / PMK.011 / 2007 Stipulation of Import Duty Tariff on Imported Rice]. Retrieved 12 6, 2016, from

http://www.sjdih.depkeu.go.id/fulltext/2007/93 PMK.011 2007Per.htm

Minot, N., \& Dewina, R. (2013). Impact of Food Price Changes on Household Welfare in Ghana. International Food Policy Research Institute. Retrieved 6 5, 2019, from https://play.google.com/books/reader?id=ARoRAgAAQBAJ\&hl=id\&lr=\&printsec=frontcover\&pg=GBS.PR1 
Nakelse, T., Dalton, T. J., Hendricks, N. P., \& Hodjo, M. (2018). Are smallholder farmers better or worse off from an increase in the international price of cereals? Food Policy, 79, 213-223.

doi:https://doi.org/10.1016/j.foodpol.2018.07.006

Simatupang, P., \& Timer, C. P. (2008). INDONESIAN RICE PRODUCTION: POLICIES AND REALITIES. Bulletin of Indonesian Economics Studies, 44(1), 65-79.

Tsakok, I. (1990). Agricultural Price Policy. New York, USA: Cornell University Press.

Vu, L., \& Glewwe, P. (2011). Impacts of Rising Food Prices on Poverty and Welfare in Vietnam. Journal of Agricultural and Resource Economics, 36(1), 14-27.

Warr, P., \& Yusuf, A. A. (2013). World food prices and poverty in Indonesia. Australian Journal of Agricultural and Resource Economics, 58(1), 1-21. doi:10.1111/1467-8489.12015

Xu, S.-W., Dong, X.-X., Li, Z. M., \& Li, G. Q. (2011). Vertical Price Transmission in the China's Layer Industry Chain: an Application of FDL Approach. Agricultural Sciences in China, 10(11), 11812-11823. doi:10.1016/S16712927(11)60181-8

Zare, R., \& Azali, M. (2015). The association between aggregated and disaggregated stock prices with monetary policy using asymmetric cointegration and error-correction modeling approaches. Review of Development Finance, 5, 64-69. doi:http://dx.doi.org/10.1016/j.rdf.2014.07.002 